\title{
'BRIDGING THE GAP': APPRAISAL OF THE FACTORS WHICH LIMIT AND IMPEDE THE REALISATION OF THE RIGHT TO WORK OF REFUGEES AND ASYLUM SEEKERS
}

\author{
by Stephen Baidoo*
}

\section{Introduction}

An asylum-seeker, in terms of the Refugees Act 130 of 1998, is 'a person who is seeking recognition as a refugee [in South Africa]'. Subsequently, the legal definitions of the term refugee contained in the Refugees Act is derived, albeit strictly, from the Refugee Convention and the OAU Refugee Convention. ${ }^{2} \mathrm{~A}$ refugee is a person who:

Owing to well-founded fear of being persecuted by reason of his or her race, gender, tribe, religion, nationality, political opinion or membership of a particular group, is outside the country of his or her nationality and is unable or unwilling to avail himself or herself of the protection of that country, or, not having a nationality and being outside the country of his or her former habitual residence is unable or, owing to such fear, unwilling to return to it; or owing to external aggression, occupation, foreign domination or other events seriously disturbing public order in either a part or the whole of his or her country of origin or nationality, is compelled to leave his or her place of habitual residence in order to seek refuge in another place outside his or her country of origin of nationality; or is a spouse or dependant of a person (recognised as a refugee). ${ }^{3}$

Essentially there are two aspects of this definition of a refugee. These are persons who: harbour a well-founded fear of persecution and are not protected in their country of origin. The elements of persecution and a lack of protection separates refugees from other groups of displaced persons or migrants who flee their country for reasons such as poverty, famine, or natural disasters. Mokgoro and O'Regan JJ, in reference to the vulnerable position of refugees, state as follows in

* $\quad$ Final year LLB student, University of Pretoria.

1 Sec $1(\mathrm{v})$ of the Refugees Act 130 of 1998.

2 Sec 3 of the Refugees Act; Art 1 of United Nations (UN) General Assembly, Convention Relating to the Status of Refugees, 28 July 1951; Art 1 of the Organisation of African Unity (OAU) Refugee Convention, adopted by the Assembly of Heads of State and Government at its Sixth Ordinary Session, Addis Ababa, 10 September 1969.

3 Sec 3 of the Refugees Act 130 of 1998. 
the case of Union of Refugee Women v Director, Private Security Industry Regulatory Authority:

Refugees had to flee their homes, and leave their livelihoods and often their families and possessions either because of a well-founded fear of persecution on the grounds of their religion, nationality, race or political opinion or because public order in their home countries has been so disrupted by war or other events that they can no longer remain there. ${ }^{4}$

In South Africa, asylum seekers and refugees are expected to integrate themselves into the society. ${ }^{5}$ In order to integrate themselves into society, refugees and asylum seekers seek employment. ${ }^{6}$ The employment of refugees and asylum seekers in South Africa is challenging. The right to work of refugees is guaranteed by section $27(\mathrm{f})$ of the Refugees Act, ${ }^{7}$ whilst section 22 provides for the right to work of asylum seekers. ${ }^{8}$ However, there is a noticeable gap between the provision of this right to work in terms of the Refugee Act and the actual recognition of this right by employers and professional councils. In practice, asylum seekers and refugees are frequently barred from exercising their right to work and thus do not enjoy these protected rights.

This article, in analysing the difficulty of attaining employment, will firstly set a foundational basis in chapter 2. Chapter 3 will deal with the international framework governing the right to work of asylum seekers and refugees. Chapter 4 of this essay will then deal with the constitutional framework governing the right to work. In chapter 5, the implications of a limitation on the right to choose employment on the right to work will be dealt with. In chapter 6 , the specific challenges faced by asylum seekers and refugees concerning their right to work will be discussed, along with recommendations for overcoming these challenges. Lastly, in chapter 7, there will be a summation of the main impediments and suggested palliatives for the realisation of the right to work of refugees and asylum seekers.

\section{Historical background on asylum and refugee laws in South Africa}

Pertaining to the historical development of the legislative and policy framework regulating rights of asylum seekers and refugees in South

42007 (4) BCLR 339 (CC) para 101.

5 C Kavuro 'Refugees and asylum seekers: Barriers to accessing South Africa's Labour Market' (2015) 19 Law, Democracy and Development 232 233-234.

6 As above.

7 Sec $27(f)$ of the Refugees Act provides that 'a refugee is entitled to seek employment.'

8 Condition 10 appearing on an asylum seeker's temporary permit, issued in terms of sec 22 of the Refugees Act.

9 Kavuro (n 5 above). 
Africa, it may be said to have gone through a first and third legislative and policy generations. ${ }^{10}$ These developments took place in response to the effects of migration within South Africa.

The first generation of asylum and refugee policies did not have refugee-specific laws and treated refugee matters under general immigration laws. ${ }^{11}$ This approach was predominant during the colonial era but persisted in certain States years after. ${ }^{12}$ This is known as the 'traditional common law approach.'13 In terms of this approach, asylum seeker and refugee policies and laws focused primarily on entry and residence by refugees while saying little on other aspects of refugee protection. ${ }^{14}$ This was the approach adopted by South Africa until the 1990s. ${ }^{15}$ Until 1998, refugee matters in the country were governed by the Aliens Control Act 40 of 1973. According to scholars, the Aliens Control Act is considered the 'last draconian piece of legislation of the Apartheid Regime.'16

The Aliens Control Act was not a comprehensive form of refugee legislation and merely addressed selected aspects of refugee problems. ${ }^{17}$ The Act was also the general Act for all immigration related matters and was primarily concerned with the control of immigration into South Africa. The Act sought to achieve this system of control through the development of the concept of a 'prohibited person.' These included amongst others: non-South African citizens who entered the country without a valid passport and visa; and those who left the country without a valid residence permit. ${ }^{18}$ Asylum applicants and refugees in term of the Aliens Control Act were either granted temporary permits to enter the country as per section $41,{ }^{19}$ or granted exemption from the entry and residence requirements of the Act on grounds of 'special circumstances; under section $29 .{ }^{20}$

10 B Rutinwa Asylum and refugee policies in Southern Africa: A historical perspective, presented at SAMP/LHR/HSRC Workshop on Regional Integration, Poverty and South Africa's Proposed Migration Policy, Pretoria, 23 April 2002 para 3.

11 Rutinwa (n 10 above) para 1.

12 As above.

13 B Rutinwa Review the law and policies relating to refugees and internally displaced persons in commonwealth countries, Consultancy Report Commissioned by the Constitutional and Legal Division, Commonwealth Secretariat, London for the Summit of the Commonwealth Heads of States and Governments, Edinburgh, June 1997 para 2.

14 As above.

15 Rutinwa (n 10 above) para 3.1.

$16 \mathrm{~K}$ Tessier 'The challenge of immigration policy in the new South Africa' (1995) 3 Global Legal Studies Journal 255.

$17 \mathrm{~J}$ Crush \& DA McDonald 'Introduction to special issue: Evaluating South African immigration policy after apartheid' (2001) 48 Africa today 4.

18 Sec 11(1) of the Aliens Control Act 40 of 1973.

19 Sec 41(1) grants the minister the discretion to "issue a prohibited person a temporary permit on the prescribed form to enter and reside in the Republic for the purpose, and subject to the other conditions, mentioned herein.'

20 Rutinwa (n 10 above) para 3.1. 
According to Rutinwa, this approach had two main shortcomings. First, in addressing refugee matters under general immigration laws, specific matters in refugee protection were not specifically dealt with. ${ }^{21}$ As such the Aliens Control Act was silent on specific refugee matters such as how refugees were to be defined, whether asylum seekers and refugees were protected from refoulement, ${ }^{22}$ by what standards refugees were to be treated and how their plight was to be resolved. 23

Secondly, Rutinwa notes that reliance on general ordinary immigration law, when confronted with the refugee problem was problematic, particularly in situations of mass influx. ${ }^{24}$ In addressing this shortfall further, Farris comments that the refugee problem has a certain level of specificity namely that it is essentially unrelated to general immigration laws or to the problems faced by other ordinary aliens. ${ }^{25}$ Classification of refugees as ordinary aliens, as seen in the Alien Control Act's failure to define a refugee, fails to address the problem. A cursory reading of the migration patterns of ordinary aliens in relation to asylum seekers and refugees denotes that immigration laws are intended to cope with the admission of individuals and not a mass influx of people. ${ }^{26}$ A negative consequence of a general application of immigration laws to refugees is a tendency to 'label all potential refugees as illegal immigrants with the attendant consequences. 27

These failings prompted the signing of the Basic Agreement between South Africa and the UNHRC (United Nations Human Rights Committee) of 1993 which, among other things, addressed the definition of a refugee. ${ }^{28}$

The third generation of asylum and refugee policies began in the 1980 s and introduced protection oriented refugee legislation based on then recent international refugee instruments. ${ }^{29}$ These laws and policies were geared towards governing all aspects of refugee protection. Such policies incorporated the basic principles espoused in any sound refugee regime, such as provisions for the definition of a refugee in accordance with the relevant international instruments at the time, institutions and procedures for refugee status

21 As above.

22 The forcible return of refugees or asylum seekers to a country where they are liable to be subjected to persecution.

23 As above.

24 Rutinwa (n 10 above) para 3.1.

25 JA Faris 'The Angolan refugees and South Africa' 2 South African Yearbook of International Law (1976) 185, quoted in $n 10$ above, para 3.1

26 As above.

27 Rutinwa (n 10 above) para 3.1.

28 As above.

29 Rutinwa (n 10 above) para 4. 
determination, non-refoulement and minimum standards of treatment. ${ }^{30}$

In this regard, South Africa enacted the Refugees Act. The Act makes provisions for the definition of a refugee, in line with accepted definitions under international instruments, establishes institutions for refugee status determination, and adjudication and lays down the procedures to be followed in this regard. The statute also makes provisions for the rights of refugees.

\section{The International framework on the right to work of refugees and asylum seekers}

The 1945 Charter of the United Nations introduced the right to work as a human right. This was done in view of the importance of this right as a 'mechanism to promote the conditions of a dignified life, socioeconomic progress and development.' 31 The right to work is further entrenched in the Universal Declaration of Human Rights (the UDHR) as a fundamental right for the promotion of a high standard of living and as a safeguard against unfair or exploitative labour practices. 32 The UDHR today has the status of international customary law, ${ }^{33}$ and has binding force on states such as South Africa. ${ }^{34}$

The right to work for refugees is guaranteed by the Refugee Convention and its Protocol. ${ }^{35}$ The Convention obligates a host state to accord to refugees lawfully staying in a host country:

(a) the most favourable treatment accorded to foreign nationals in the same circumstances, as regards the right to engage in wage-earning employment; ${ }^{36}$ and

(b) treatment as favourable as possible and, in any event, not less favourable than that accorded to foreign nationals generally in the same circumstances, as regards the right to engage in self-employment; ${ }^{37}$ or the right to practise a liberal profession. ${ }^{38}$

30 As above.

31 Art 55(a) of the United Nations, Charter of the United Nations, 24 October 1945, 1 UNTS XVI http://www.refworld.org/docid/3ae6b3930.html (accessed 2 June 2016).

32 Art 23 of the United Nations General Assembly, Universal Declaration of Human Rights, 10 December 1948, 217 A (III) http://www.refworld.org/docid/ 3ae6b3712c.html (accessed 2 June 2016).

33 Kavuro (n 5 above) 235.

34 See A D'Amato 'Human rights as part of customary international law: A plea for change of paradigms' (1995) 25 Georgia Journal of International and Comparative Law 51, where he states that, "custom is the only universal source, generating law that is binding on all nations (including new nations).'

35 The 1967 Protocol Relating to the Status of Refugees, General Assembly, Res 2198 (XXI) of 16 December 1967.

36 Art 17(1) of the Refugee Convention.

37 Art 18 of the Refugee Convention.

38 Art 19(1) of the Refugee Convention. 
Therefore, in terms of the Refugee Convention, a host state should, by virtue of a refugee's status, accord refugees and asylum seekers favourable opportunities to earn a living through work. The Refugee Convention does not define what constitutes favourable treatment, although such treatment should be seen as 'favourable employment opportunities that are crucial and essential for refugee livelihood. ${ }^{39}$ The term 'refugees lawfully staying' refers to legally recognised refugees and by implication asylum seekers who are legally in a host country for reasons other than physical presence, brief presence, or whose stay is purely temporary. ${ }^{40} \mathrm{Da}$ Costa argues that the use of the term 'all refugees' entrenched under the Refugee Convention refers to:

Recognised refugees, asylum seekers, undocumented (or illegal) asylumseekers or those refugees who overstayed the period for which they were permitted to sojourn or have violated one or more conditions of their sojourn. ${ }^{41}$

Furthermore, the Refugee Convention requires that States must consider conferring upon refugees' similar rights to engage in wage earning employment. ${ }^{42}$ The Refugee Convention notes that in most instances there are restrictions imposed on non-citizens in general, with regards to accessing certain aspects of the labour market, so as to ensure full participation from the citizens of a particular state in crucial labour sectors. Essentially, states are given a margin of discretion in determining the manner in which the right to work for non-citizens is framed. Article 2(3) of the ICESCR allows 'developing countries' to determine to what extent they would guarantee (the right to work) to non-citizens. ${ }^{43}$ With regards to the imposition of these restrictive measures, the Refugee Convention precludes their application to refugees in certain instances, namely: where a refugee has completed three years' residence in the country, or is married to a citizen, or is a parent to one or more children possessing the nationality of a host country. ${ }^{44}$ Therefore, the measures adopted to safeguard the national labour market, should not apply as severely to refugees who comply with these categories, as it does to other noncitizens. ${ }^{45}$

39 Kavuro (n 5 above) 237.

40 R Costa 'Rights of refugees in the context of integration: Legal standards and recommendations' prepared on behalf of United Nations High Commissioner for Refugees, Legal and Protection Policy Series, POLAS/2006/02.

41 As above.

42 Art 17(3) of the Refugee Convention.

43 Kavuro (n 5 above) 237.

44 Art 17(2) of the Refugee Convention.

45 A Edwards 'Gainful employment' in A Zimmermann (ed) The 1951 Convention Relating to the Status of Refugees and its 1967 Protocol: A commentary (2011) 954. 
Human rights treaties have entrenched the right to work for the purpose of "promoting social progress and a better standard of life.,46 Therefore, any denial of this right essentially prevents individuals from attaining this satisfactory standard of living envisioned in the various human rights treaties mentioned above. Furthermore, the 1986 Declaration on the Right to Development, along with the 1993 Vienna Declaration and Programme of Action, recognise that only through respect for and observance of recognised human rights can individuals essentially live fulfilled lives. Both declarations recognise the interdependence of fundamental human rights and the need for equal observance of such rights in order to ensure their realisation. ${ }^{47}$

The right to work therefore is a fundamental human right derived 'from the inherent dignity of the human person." 48 The right includes the right of 'everyone to the opportunity to gain his or her good living by work. ${ }^{49}$ It is furthermore, interdependent on other fundamental rights, as the right to life, equality, and dignity. ${ }^{50}$ Therefore, a state cannot deny refugees or asylum seekers the right to work as it forms an integral part of various basic human rights. ${ }^{51}$ Fundamental human rights are afforded to and should be enjoyed by 'all people in all places.' 52 Therefore, its enjoyment should not be restricted to citizens, as categorisation based on place of birth or origin cannot act as a basis upon which this right is denied.

\section{The national framework on the right to work of refugees and asylum seekers}

Section 22 of the Constitution states that: 'Every citizen has the right to choose their trade, occupation or profession freely. The practice of a trade, occupation or profession may be regulated by law. ${ }^{2} 3$ This particular provision in the Constitution is problematic in that it seems

46 Kavuro (n 5 above) 237.

47 Art 6(2) of the Declaration on the Right to Development, General Assembly, Res $41 / 128$ of 4 December 1986, states that '[a]ll human rights and fundamental freedoms are indivisible and interdependent; equal attention and urgent consideration should be given to the implementation, promotion and protection of civil, political, economic, social and cultural rights'. This view is shared in art 5 of the Vienna Declaration and Programme of Action, adopted by the World Conference on Human Rights, Vienna, 25 June 1993.

48 Kavuro (n 5 above) 237.

49 Art 6 of the International Covenant on Economic, Social and Cultural Rights, General Assembly, Res 2200A (XXI) of 16 December 1966, (the ICESCR).

50 Art 2(1) of the International Covenant on Civil and Political Rights, General Assembly, Res 2200A (XXI) of 16 December 1966 (the ICCPR).

51 Kavuro (n 5 above) 237.

52 As above, citing J Chapman et al 'Rights based development: The challenge of change and power' (2005), Global Poverty Research Group, paper written for the 2005 conference, Winners and Losers from Rights-based Approaches to Development.

53 Constitution of the Republic of South Africa, 1996 (the Constitution). 
to exclude refugees, asylum seekers and non-citizens in general from participation in the South African labour market.

In response to this, South African courts (the Constitutional Court and the Supreme Court of Appeal respectively) have reviewed the constitutionality of section 22 concerning the restriction on refugees' rights in respect of accessing the labour market in the Union of Refugee Women $v$ Director, Private Security Industry Regulatory Authority case and the Somali Association of South Africa $v$ Limpopo Department of Economic Development Environment \& Tourism case. ${ }^{54}$ In terms of the court's decisions, there is an aversion to the State's argument that refugees and asylum seekers are totally prohibited from the right to work on the basis of section 22 of the Constitution. In the Union of Refugee Women $v$ Director, Private Security Industry Regulatory Authority case the Constitutional Court articulated the steps necessary for a legitimate limitation of this right in regards to refugees and asylum seekers, the court stated that. ${ }^{55}$

Any restrictive measures imposed on refugees and asylum seekers for the protection of national security or the broad public interest must be rational, reasonable and justifiable in terms of the limitation clause or should not have the potential to impair the essential content of dignity

As such the right to work of refugees and asylum seekers in not explicitly prohibited in terms of the Constitution.

The main arguments against the right to work have been directed at asylum seekers. It has been argued that apart from basic humanitarian assistance asylum seekers enjoy only the right to basic education. ${ }^{56}$ Prior to the 2008 amendment to the Refugees Act, the Standing Committee for Refugee Affairs (the SCRA) determined the conditions of an asylum seeker's stay in the country whilst a decision on the approval or rejection of their application was pending. ${ }^{57}$ The conditions adopted by the SCRA precluded an asylum seeker from enjoying the rights to work and to education for the first 180 days from the date of their application for asylum. ${ }^{58}$ After the 180 days, an asylum seeker could apply for special consideration to be permitted to work while the outcome of the application for asylum was still pending. In 2008 this position changed, when the Refugees Act was revised in response to gaps in the refugee framework. The amendments prescribed the conditions of asylum seekers' stay and

542015 (1) SA 151 (SCA).

55 Union of Refugee Women (n 4 above) paras 34 \& 66-77; sec 28 of the Constitution.

56 GS Goodwin-Gill \& J McAdam The refugee in international law (2007) 298-299.

57 The main conditions of asylum are provided on the asylum seeker permit issued in terms of sec 22 of the Refugees Act. Reg 7 of the Refugee Regulations (Forms and Procedures) of 2000 read together with the form prescribed by annex 3, provide the other conditions of their stay.

58 Minister of Home Affairs $v$ Watchenuka 2004 (1) All SA 21 (SCA) para 23. 
provided for the recognition of their rights. ${ }^{59}$ These are the rights contained in the Bill of Rights insofar as they apply to everyone. ${ }^{60}$ The 2008 revision still fails to expressly state that asylum seekers are 'fully' protected. On this basis, some scholars argue that asylum seekers, in principle, are merely granted the right to stay in South Africa and not to work and study while waiting for recognition as refugees. ${ }^{61}$ This view is not tenable considering that asylum seekers are "jurisprudentially and statutorily allowed to work." 62

With regards to the jurisprudential recognition of the right to work of asylum seekers, the case of Minister of Home Affairs $v$ Watchenuka was a landmark decision. The prohibition on the rights of asylum seekers to work was judicially reviewed for the first time in the case of Watchenuka. In this case, a Congolese national and her disabled son sought employment in order to pay for the son's tuition when, in terms of the conditions set by the SCRA, they were both deemed by the state as prohibited from seeking employment. In its analysis of this prohibition, the SCA took cognisance of the fact that there were no refugee camps in South Africa and that little to no humanitarian and social assistance was offered by the government to asylum seekers. Accordingly, the SCA ruled that such a general prohibition was unlawful and fundamentally violated the right to human dignity on the basis that: ${ }^{63}$

Where employment is the only means for the person's support and where education offers an opportunity for human fulfilment at a critical period, the right to dignity is implicated.

With regard to the right to work, the SCA articulated that the denial of the right to work 'severely restricts asylum seekers' ability to support themselves and their families and to live without positive humiliation and degradation. ${ }^{\prime 64}$ The SCA reasoned further that such a denial would: 65

Aggravate and perpetuate their destitution and have the effect of objectifying and debasing asylum seekers in the context of compelling them to resort to crime, or to begging, or to foraging.

The SCA stated that the 'general prohibition of employment and study for the first 180 days after a permit to sojourn in South Africa has been issued is in conflict with the Bill of Rights. ${ }^{66}$ In light of the case of

59 Refugees Amendment Act 33 of 2008.

60 Sec 27A of the Refugees Act.

61 P Rugunanan \& R Smit 'Seeking refuge in South Africa: challenges facing a group of Congolese and Burundian refugees' (2011) 28 Development Southern Africa 708.

62 Kavuro (n 5 above) 242.

63 Watchenuka (n 58 above) paras 32-36.

64 Watchenuka (n 58 above) para 32.

65 As above.

66 Watchenuka (n 58 above) para 24. 
Watchenuka, the SCRA changed its original position and allowed asylum seekers to undertake employment and education. ${ }^{67}$ As such the right to work of refugees and asylum seekers is provided for in South African legislation.

\section{The right to work in the context of the freedom to choose employment for refugees and asylum seekers}

The choice of employment has an impact on the right to work of refugees and asylum seekers. Enforcing the right to work does not guarantee the right to choose any form of employment. States faced with the responsibility of raising the living standards of their citizens enjoy unfettered discretion to include or exclude non-citizens. ${ }^{68}$ In the Watchenuka case, the court highlighted that in various jurisdictions it is generally held that the 'freedom to choose employment is not universally accepted as a universal right. ${ }^{69}$ Thus, although international law views the right to work as a fundamental human right it can still be restricted to safeguard national interests and development. ${ }^{70}$

In the Constitutional Court judgement in the Union of Refugee Women $v$ Director, Private Security Industry Regulatory Authority case, the Court was tasked with dealing with the constitutionality of the state's prohibition of refugees rendering a 'security service as security service providers [without] permanent residence statuses. 71 The court determined that this prohibition was constitutional. It amounted to fair discrimination and did not 'materially invade their dignity because the private security industry framework offered a reasonable measure of flexibility, allowing refugees to engage in the security service industry, on good cause shown."72

As such, if there is no express restriction on a sector in the labour market refugees and asylum seekers are free to choose employment opportunities within that sector. ${ }^{73}$ However, these restrictions should not be absolute. Legislation should in such an instance be flexible to

67 Condition 10 appearing on an asylum seeker's temporary permit, issued in terms of sec 22 of the Refugees Act now allows asylum seekers to work, this condition was not present prior to the Watchenuka case.

68 Kavuro (n 5 above) 236.

69 Watchenuka (n 58 above) para 30.

70 Kavuro (n 5 above) 236.

71 Union of Refugee Women (n 4 above) paras 1-3.

72 Union of Refugee Women (n 4 above) para 86.

73 Kavuro (n 5 above) 240. 
accommodate for deviations in certain circumstances to ensure that there is no violation of the equality provision in the Constitution. ${ }^{74}$

In the Somali Association of South Africa $v$ Limpopo Department of Economic Development Environment \& Tourism case in 2015, the Supreme Court of Appeal condemned the restrictive labour policies practised by the state. In this case, the state argued that its refusal to issue licenses to refugees and asylum seekers so as to prevent them from trading in spaza and 'tuck' shops and further, that closing down their businesses was legal as it was in line with section 22 of the Constitution. ${ }^{75}$ The state argued that section 22 of the Constitution restricts the freedom of non-citizens to choose an occupation. ${ }^{76}$ The state further argued that asylum seekers' and refugees' right to seek employment in terms of section 27 of the Refugees Act, did not include a right to engage in self-employment. ${ }^{77}$ The court in response made reference to Articles 17(2) and 17(3) of the Refugee Convention and read them together with section $27(\mathrm{f})$ of the Refugees Act, the court on that basis held that, both frameworks 'grants refugees exemption from restrictive measures under certain circumstance' and demands a host state to 'give sympathetic consideration to assimilating the rights of all refugees with regard to wage-earning employment to those of nationals,' respectively. ${ }^{78}$ The courts viewed such a deprivation as an attempt on the part of the state to 'impoverish refugees and asylum seekers' so as to ensure their destitution, thus, indirectly forcing them to leave South Africa. ${ }^{79}$ The Court held that the attitude of the state in this regard defeated its international obligation to refugees and asylum seekers. ${ }^{80}$

Essentially these cases illustrate that refugees and asylum seekers are not barred from seeking and gaining employment or engaging in self-employment and any legal restriction with regards to the choice of employment is to be challenged unless reasonably and rationally justified. 


\section{Specific factors which impede the realisation of the right to work of asylum seekers and refugees and suggested palliatives}

\subsection{Legal security}

Refugees and asylum seekers need greater legal security to effectively integrate into South Africa. The lack of legal security surrounding their legal status affects their ability to engage in income-earning activities in a legal manner. Their legal security in this instance refers to the provision of legal and valid documentation. ${ }^{81}$ The legal security of refugees and asylum seekers is of importance in that they cannot apply for employment or register with professional councils 'unless they possess lawful and valid documents provided in terms of the Refugees Act. ${ }^{82}$ Therefore, there is an impediment to realising their right to work when acquiring these documents becomes difficult.

The Department of Home Affairs is tasked with issuing refugees and asylum seekers with the necessary documentation, in terms of the Refugees Act, in a timeous manner. This was confirmed in the Kiliko $v$ Minister of Home Affairs case, ${ }^{83}$ where it was indicated that the Department is tasked with the 'processing of asylum applications within a reasonable time. ${ }^{84}$ Regardless of this legal obligation, most asylum applicants wait for 5 years or longer for the outcome of the adjudication of their cases. ${ }^{85}$ The problem regarding the backlog in asylum applications was also recognised in the Somali Association of South Africa $v$ Limpopo Department of Economic Development Environment \& Tourism case. In this case, parties involved in the asylum determination process accepted that in most instances asylum applications take up to three years to be finalised. ${ }^{86}$ The Somali Association of South Africa $v$ Limpopo Department of Economic Development Environment \& Tourism case was decided nine years after the Kiliko $v$ Minister of Home Affairs case, this shows that the backlog problems still continue. IOL in 2009 reported that Home Affairs would face up to 30 years to clear the backlog. ${ }^{87}$

This backlog in asylum applications severely impacts on the ability of asylum seekers to integrate into society, specifically with regards

81 Kavuro (n 5 above) 255.

82 As above.

832006 (4) SA 114 (C).

84 Kiliko (n 83 above) para 25.

85 LB Landau 'Urbanisation, nativism, and the rule of law in South Africa's forbidden cities' (2005) 26 Third World Quarterly 1121-1123.

86 Watchenuka (n 58 above) para 44.

87 L Jones 'Home Affairs needs 30 years to clear backlog' IOL 11 October 200921. 
to accessing and competing in the national labour market. ${ }^{88}$ Registration with some professional councils is limited to those with refugee status and does not include asylum seekers. ${ }^{89}$ Therefore, backlogs in the asylum process affect the transition from asylum seeker to refugee and therefore place many asylum seekers in a position where they are relegated to a small portion of the labour market. Therefore, a backlog in the asylum application process affects thousands of asylum seekers from qualifying as refugees and registering for certain professional councils and in applying for employment.

The backlog also affects refugees as it severely impacts their ability to renew and validate their stay upon the expiry of their refugee permit (which prescribes a stay period in South Africa). If the documents of refugees are invalid, they cannot be registered and can thus not seek employment. ${ }^{90}$ Even if they are employed, they cannot legally work as they will be deemed illegal foreigners. ${ }^{91}$

Furthermore, a refugee permit is in the form of a refugee identity document. This document is maroon and thus different from the green bar-coded identity document owned by South Africans and permanent residents. ${ }^{92}$ The difference in colour and form has created the impression that they are not legitimate. ${ }^{93}$ The maroon identity document creates a situation where refugees are automatically not considered for employment by various companies or institutions. ${ }^{94}$

Lastly, the classification of refugees in the labour market affects their ability to fully realise their right to work. A case in point is the Health Recruitment Policy which categorises refugees as temporary residents. ${ }^{95}$ This Policy was challenged in the Ndikumdaryi $v$ Valkenberg Hospital and Others case. ${ }^{96}$ Generally, temporary residents are only eligible for 'fixed term contracts' or 'part-time employment' but not permanent employment, regardless of whether the job offered is in the public or private sector. ${ }^{97}$ In the Ndikumdavyi $v$ Valkenberg Hospital case the applicant argued that the Health Recruitment Policy was discriminatory, however the court left this question open. ${ }^{98}$ The Labour Court in Ndikumdavyi $v$ Valkenberg Hospital case, however, endorsed the restriction of eligibility to

95 Rule 3.5 of the Policy of the Department of Health on Recruitment and Employment of Foreign Health Professionals in the Republic of South Africa of 2006 (Health Recruitment Policy).

962012 (8) BLLR 795 (LC).

97 Ndikumdavyi (n 96 above) para 6.

98 Ndikumdavyi (n 96 above) paras $14 \& 27$. 
citizens and permanent residents. ${ }^{99}$ However a prohibition on the recruitment to a permanent position of a refugee who has fulfilled one of the requirements of section 17(2) of the Refugee Convention would amount to a violation of the Refugee Convention. ${ }^{100}$

\subsection{Restrictive requirements for employment}

Non-citizens (who do not have a permanent residence status) are required by the Immigration Act to apply for a work permit before undertaking any self-employment activities or wage-earning employment. ${ }^{101}$ The work permits are further only granted if the individual fulfils certain employability conditions, namely, (i) being highly skilled and (ii) unavailability of a suitable citizen. ${ }^{102}$

Although highly-skilled qualifications or experience is required by the Immigration Act as a prerequisite to employment, ${ }^{103}$ the Refugees Act sets a lower threshold. ${ }^{104}$ However, in practice, most professional councils set similar requirements as the Immigration Act for all noncitizens regardless of their refugee or asylum-seeker status. ${ }^{105}$ For example, the Health Recruitment Policy states that foreign health professionals can seek employment and be granted employment on condition that "no qualified South African citizen or permanent resident is readily available or has applied for the position.'106 On that basis, refugees and asylum seekers cannot be employed unless they are 'highly-skilled.' These stringent statutory conditions do not and should not apply to refugees and asylum seekers. ${ }^{107}$ As stated previously, the Refugee Convention prescribes that labour restrictions imposed on other non-citizens should not be applied to refugees and asylum seekers. 108

Regardless of this approach, employers and professional councils in South Africa still extend these restrictive measures to refugees and asylum seekers. ${ }^{109}$ Most employers, according to the Consortium for Refugees and Migrants in South Africa (CorMSA), discriminate against refugees and asylum seekers - mainly because they are non-citizens

99 Ndikumdavyi (n 96 above) para 26

100 Where a refugee has completed three years' residence in the country, or is married to a citizen, or is a parent to one or more children possessing the nationality of a host country.

101 Kavuro (n 5 above) 246.

102 Sec 19(2) (a) of the Immigration Act states that, 'a work permit or visa can be granted if no South African citizen with qualifications or skills and experience equivalent to those of the applicant can, despite a diligent search, be employed.'

$103 \mathrm{Sec} 2(1)(j)(i)(c c)$ read together with sec 19(2)(a) of the Immigration Act.

104 Kavuro (n 5 above) 259.

105 As above.

106 Rule 5.1 .1 of the Health Recruitment Policy.

107 Kavuro (n 5 above) 246.

108 Art 17(2) of Refugee Convention.

109 Kavuro (n 5 above) 247. 
and further that, employers are not informed about refugee rights. ${ }^{110}$ There is a general fear amongst employers of a possible criminal sanction that might be imposed on them if they employ refugees and asylum seekers. ${ }^{111}$ This approach, therefore, makes it almost impossible for refugees and asylum seekers to gain employment.

\subsection{Difficult registration requirements of professional councils}

Most foreign and national professionals alike have to register with a professional council in order to be able to undertake certain professions. ${ }^{112}$ Thus, the opportunity to register with a professional council is an integral component of realising one's right to work within South Africa.

Some professional councils place the onerous requirement of permanent residence status as a requirement for registration. These include the Law Society of South Africa (LSSA) and the Security Industry Regulatory Authority (SIRA). ${ }^{113}$ This effectively ensures that refugees and asylum seekers cannot work as attorneys or security service providers. Although their freedom to work is limited, this article argues that refugees cannot be "wholly deprived of the right to work as attorneys or security service providers."114

The right to work ensures effective integration into society, and as stated in those chapters, any limitation on this right should be reasonable and justifiable in light of the values of human dignity, equality and freedom. This article argues that the requirements for registration in these professional councils should be flexible so as to include as a minimum, refugees, noting the similar legal position refugees share with permanent residents. ${ }^{115}$ This was observed by the court in the Union of Refugee Women $v$ Director, Private Security Industry Regulatory Authority case. ${ }^{116}$

As such, in light of this similarity, refugees and permanent residents should enjoy the right to work in a similar manner. Otherwise, the requirement on refugees to be permanent residents before they have a right to work violates section 27(f) of the Refugees

110 CorMSA 'Protecting Refugees, Asylum-Seekers and Immigrants' (2009) 106, states that refugees and asylum seekers are denied employment on the basis of being non-citizens; L Mazzocchini 'Policy implication learned from the analysis of the integration of refugees and asylum seekers at tertiary education in Cape Town' unpublished Master's thesis, University College Dublin, 2007/2008 43, states that, 'employers ... are neither familiar with the documentation issued to refugees and asylum-seekers nor with the rights derived from such documentation.'

111 The stipulated penalty in terms of sec 49(3) of the Immigration Act for an offender is a (just) fine or imprisonment not exceeding one year.

112 Kavuro (n 5 above) 247.

113 Kavuro (n 5 above) 257.

114 As above.

115 Kavuro (n 5 above) 257.

116 Union of Refugee Women (n 4 above) para 99. 
Act. Refugees are traditionally encouraged to apply for permanent residence after five years of continuous residence in South Africa from the date on which they were granted a refugee permit. Upon attaining permanent residence, a refugee is no longer governed in terms of the Refugees Act, as they become permanent residents for the purposes of the Immigration Act. Regardless of this traditional approach, in light of the right to work, the Refugees Act requires that professional councils should allow recognised refugees to register. Therefore, in doing so, the permanent residence and citizenship requirements for registration with professional councils will not act as a barrier for refugees.

Registration with some professional councils is limited to those with refugee status and does not include asylum seekers. ${ }^{117}$ As stated in chapter 3, previously refugees were allowed to work to the exclusion of asylum seekers. This position changed in the Watchenuka case. In light of the change in the position concerning the right to work of asylum seekers, this article argues that professional councils that permit registration to those with refugee status should also include asylum seekers.

Professional councils such as the engineering sector, allow refugees but prevent asylum seekers from registering. ${ }^{118}$ Furthermore, the Health Recruitment Policy does not extend eligibility to asylum seekers. The Policy states that asylum seekers cannot be employed 'on a full-time basis on the fixed establishment or enrolled for the examination processes by a Health Professional Council in South Africa (HPCSA). 119 Even if asylum seekers are offered jobs, their employment will not be endorsed by the HPCSA until they become recognised as refugees. ${ }^{120}$ The Policy further prohibits their recruitment as interns or in the community services. ${ }^{121}$ These prohibitions violate the Refugee Convention, the amendments to the Refugees Act and are not in line with the Watchenuka case. ${ }^{122}$

Thus, professional councils should consider that asylum seekers need work to survive. Total exclusion forces asylum seekers to result to illegal activities as a coping mechanism. Where asylum seekers have much-needed skills, the state should seek to utilise these skills for its benefit.

117 Kavuro (n 5 above) 256

118 Kavuro (n 5 above) 258; Sec 6(1) (a) \& (g) of the Engineering Profession Act 46 of 2000.

119 Rule 3.5.2 of the Health Recruitment Policy.

120 As above.

121 Rules 10.1 and 11.3 of the Health Recruitment Policy.

122 As argued by Kavuro ( 5 above) 258. 
To fix this issue this article argues that the rights of refugees should be given the appropriate attention when professional councils, design and develop their recruitment and registration policies. ${ }^{123}$ Preferably a general 'policy on recruitment, employment and registration' developed in compliance with the Refugees Act should act as the template when professional councils frame their policies regarding refugees and asylum seekers. ${ }^{124}$ This will avoid inconsistencies and will ensure the full realisation of the right to work of refugees and asylum seekers.

\section{Conclusion}

In terms of international law, the right to work is a fundamental human right and should therefore be afforded to refugees and asylum seekers. Constitutionally South Africa is a party to the Refugee Convention. The Refugees Act is, therefore, the legislative realisation of the State's international obligations. The Refugees Act essentially guarantees the right to work of refugees and asylum seekers. The limitation on the freedom to choose employment has affected the realisation of the right to work. Due to this limitation, professional councils have been ready to disregard the right to work of asylum seekers and refugees on the basis of section 22 of the Constitution in the supposed interest of citizens.

The resultant effect of the limitation of the right to work in the context of the choice of employment has been that certain restrictions have been placed in various labour sectors which effectively exclude asylum seekers and refugees.

The backlog in the asylum application process, the classification of asylum seekers and refugees in certain professions and the aesthetic difference of the asylum seeker and refugee permits affects the ability of asylum seekers and refugees to effectively participate in the labour market. The highly restrictive labour requirements placed on general non-citizens has been incorrectly applied to refugees and asylum seekers by employers and professional councils. Lastly, the stringent requirement for registration in a professional council makes it nearly impossible for asylum seekers and refugees to find employment.

This article argues that the limitation on the right to choose employment should never be absolute and as such, all employers and professional councils must make provision for employment of refugees and/or asylum seekers in various labour sectors. Further, that the 
asylum application process needs to clear its backlog in order to allow asylum seekers and refugees to timeously acquire and renew their permits so as to lawfully apply for work. Furthermore, the restrictive skills requirements should not apply at all to refugees who comply with article 17(2) of the Refugee Convention and should be relaxed in the case of other refugee and asylum seekers. Lastly, professional councils which permit refugees to register should similarly permit asylum seekers in light of the Watchenuka case and the similarly vulnerable position occupied by both asylum seekers and refugees. It is imperative that the right to work of refugees and asylum seekers is realised so as to afford them the chance to change and improve their standing in society. 